\title{
Jubileusz Profesora Marcelego Kosmana
}

W dniach 16-17 maja 2000 r. na Uniwersytecie im. Adama Mickiewicza w Poznaniu odbyla się - zorganizowana przez Zakład Dziennikarstwa Instytutu Nauk Politycznych i Dziennikarstwa - ogólnopolska konferencja naukowa: „Kultura polityczna w Polsce - wizje przyszłości”. Jest to trzecia konferencja naukowa poświęcona kulturze politycznej, tym razem $w$ aspekcie wizji przyszłości, tym odległym, już zweryfikowanym przez życie, a także nam współczesnym, które na te weryfikacje dopiero czekają. Poprzednie konferencje odnosiły się do relacji między historiografią i politologią ( 29 i 30 listopada 1995 r.) oraz mitów i faktów (22 i 23 kwietnia 1998 r.). Inicjatorem tych spotkań jest prof. Marceli Kosman. Warto wspomnieć, iż tematyka ta wiąże się autorsko ze studiami pt. Z rozważań nad kulturq politycznq w Polsce, które ukazały się w 1998 roku nakładem Wyższej Szkoły Zarządzania i Bankowości w Poznaniu. Tutaj właśnie w ubiegłym roku został zorganizowany Instytut Historii Politycznej, którego pomysłodawcą jest Marceli Kosman, pełniący funkcje prorektora do spraw politologii.

Motywem przewodnim konferencji były wizje przyszłości, funkcjonujące w obrębie szeroko rozumianej kultury politycznej. Temat ten, czego dowodem były wystąpienia zaproszonych gości, związany jest $z$ polityka, niezależnie od epok historycznych, panujących ideologii czy systemów społecznych. Wygloszone referaty wskazywały nie tylko na konkretne przykłady pojawiających się prognoz $w$ minionych epokach, ale również omawiały wizje najnowsze, sprawdzone oraz oczekujące na sąd, które dotyczq̨ zarówno kompetencji polityków, jak i kondycji ich społecznego zaplecza.

W pierwszym dniu obrad swoje referaty zaprezentowało siedmiu prelegentów. Wystąpieniem otwierającym obrady byl referat wygloszony przez prof. Gerarda Labude, zatytułowany „Przelom innowacyjny" w rozwoju wspólczesnej kultury. Następnie prof. Bogdan Koszel przedstawił Polske w Unii Europejskiej w oczach Zachodu. W zainteresowania przyszłością badań Kazimierza Podolskiego (1923-1995) przeniósł słuchaczy prof. Andrzej Chodubski, natomiast wystąpienie prof. Karola Janowskiego zdominowała problematyka poświęcona refleksji nad kulturą polityczną Polaków.

Kolejni mówcy skupili się na funkcjonowaniu wizji przyszłości w relacjach państwo a Kościół, dokumentując swoje przemyślenia wieloma interesujacymi przykładami (prof. Zygmunt Zieliński Margines egzystencji politycznej Kosciola w PRL oraz Krzysztof Mądel, Czy Jezuici wdawali sie $w$ polityke?). Odczyt prof. Lecha Ludorowskiego na temat zapomnianych ogniw motywu krzyżackiego w literaturze i kulturze XIX w. zamknął pierwszą cześć wystąpień. Ożywioną dyskusję zdominował wątek racjonalności i obiektywizmu w snuciu prognoz i przewidywaniu najbliższych, bo związanych na przykład z przyjęciem Polski do Unii Europejskiej, oraz kwestii terminologicznej kultury politycznej $w$ Polsce.

W godzinach popołudniowych Salę Lubrańskiego w Collegium Minus naszẹ Almae Matris wypełnił thum gości, którzy zebrali się, aby uczcić jubileusz 60. urodzin Profesora Marcelego Kosmana.

Wydana na tę okoliczność księga pamiątkowa będąca dowodem uhonorowania dostojnego Jubilata skupiła 50 prac uczonych z ośrodków naukowych znajdujących się zarówno w Polsce, jak i za granicą. Omawiana księge przygotował Instytut Nauk Politycznych i Dziennikarstwa UAM.

Tom otwiera wprowadzenie zatytułowane Droga historyka ku wspólczesności autorstwa prof. Jana Seredyki oraz Slowo o Jubilacie doc. Jana Załubskiego, w którym czytamy: „Profesor, autorytet wśród historyków, bardzo szybko zdobyl uznanie $i$ silnq pozycje w gronie politologów. Jest jednym $z$ inspiratorów badań szeroko rozumianej kultury politycznej. (...) Napisal $i$ opublikowal ponad 40 ksiqżek, w prasie ukazalo się okolo tysiqca artykulów. Każdy rok wzbogaca bibliografí prac plodnego autora o kilkanascie, a bywa, że $i$ o kilkadziesiqt pozycji". 
Całość publikacji poprzedzona została, zgodnie z istniejącym zwyczajem, bibliografią Jubilata za lata 1963 do 2000. Imponująca, zawierająca ponad tysiąc pozycji bibliografia wskazuje na potencjał badawczy Profesora i wciąż nie słabnące siły na drodze dalszych poszukiwań naukowych. Tytuł księgi - Przeszlość odlegla i bliska wyznacza jej zawartość, a zarazem odzwierciedla glówne nurty w drodze badawczej uczonego, która zawiera się między dwiema dyscyplinami - historia i politologią. Nie dziwi więc fakt, że reprezentują je również autorzy artykułów - przyjaciele Jubilata, koledzy, współpracownicy i uczniowie. Nadesłane artykuły pogrupowano w czterech działach tematycznych: Historia, Politologia, Mass media i Varia według nazwisk autorów w porządku alfabetycznym. Nie przypadkowo organizacja konferencji na temat kultury politycznej zbiegla sie z obchodami jubileuszu Profesora Kosmana. Powszechnie wiadomo, iż temat ten jest Jubilatowi szczególnie bliski i wnikliwie poruszany w licznych opracowaniach na temat szeroko pojętej kultury.

Kultura polityczna pozostaje zwykle pod silnym wpływem zjawisk nam wspólczesnych. Nic dziwnego, że właśnie ten element został najmocniej wyeksponowany w referatach składających się na drugi dzień konferencji, który obfitował w jedenaście wystąpień. Otwarcie obrad rozpoczął prof. J. Pảnek z Pragi (Stavovska vize strednii Evropy. Od protiturecke aliance $k$ evangelicke konfederaci). Następnie prof. W.A. Serczyk nakreślił wizje przyszłości w odniesieniu do szans Hadziacza, zaś prof. J. Byliński zaznajomił słuchaczy ze szlacheckimi koncepcjami ustroju Rzeczpospolitej z przełomu XVI i XVII wieku. Dalsze wystąpienia koncentrowały się na kulturze politycznej osiemnastowiecznej Polski (prof. M. Żyromski) a także twórcach graficznych obrazów Śląska (prof. W. Kaczorowski). Walor ponadczasowy miały dociekania nad oceną postaci Augustyna Kordeckiego wygłoszone przez prof. M. Kosmana oraz zarys projektów nowej polityki europejskiej wobec Rosji Stanisława Leszczyńskiego (prof. A.J. Zakrzewski i mgr M. Skwarczyńska). Referat ks. prof. S.Z. Jabłonskiego przybliżył kwestię Jasnej Góry w swiadomości narodowej $X I X$ wieku.

Ostatnie trzy wystąpienia odbiegały od wcześniej wygłoszonych, koncentrowały sį̨ bowiem na omówieniu funkcjonowania wizji przyszłości w kulturze politycznej Polski po roku 1989 i stały się głównym przyczynkiem do ożywionej dyskusji zamykającej obrady. Szczególnie tekst prelegenta K. Borowczyka - Wizje polski przy okraglym stole oraz artykuł A. Kasińskiej - Metryki na temat elit politycznych w Polsce po 1989 roku. Nie było wątpliwości co do zasadności rozważań, powiązań tematów wystąpien z tytułem konferencji: Kultura polityczna w Polsce - wizje przyszlości.

Wielowątkowość omawianych zjawisk podczas spotkań wskazała na potrzebę wspólnych studiów prowadzonych przez reprezentantów różnych dyscyplin humanistycznych. W tym wypadku prym wiedli historycy i politolodzy. Dorobek majowej konferencji stanowi ważny wkład w rozwój badań nad kulturą polityczną. Organizatorzy przygotowują publikację na podstawie zaprezentowanych referatów oraz dyskusji.

Zaneta Polowczyk

\section{Edukacja 2000. Opozycja: Elitaryzm - Egalitaryzm. Konferencja naukowa WSP w Slupsku, 29-30 maja 2000 r.}

Wydział Filozoficzno-Edukacyjny WSP w Słupsku zorganizował wraz z oddziałem słupskim Polskiego Towarzystwa Pedagogicznego konferencje naukową na powyższy temat. Obrady odbywały się w Ustce w ośrodku Jantar. Wzięli w nich udział przedstawiciele kilku ośrodków naukowych, m.in. z Bydgoszczy, Częstochowy, Kielc, Koszalina, Krakowa, Katowic, Olsztyna, Poznania, Słupska, Szczecina, Torunia, Trójmiasta, Wrocławia i in. 